\title{
CHANGE OF MANAGEMENT PARADIGM? - PILOT SURVEY AT THE UNIVERSITY OF ECONOMICS PRAGUE
}

\author{
Ludmila Mládková
}

\author{
Department of Management, Faculty of Business Administration, University of Economics Prague, \\ W. Churchilla 4, Prague 3, 130 00. Czech Republic \\ E-mail:mladkova@vse.cz
}

\begin{abstract}
The paper compares latest views of theorists and practitioners on development of management. Management as a scientific discipline develops over 150 years. During this period many new practices, processes, structures and techniques appeared. Some of them were remarkable management innovation that changed ways how things happen in organization. Recent years brought big changes like globalization, and ICT development to our lives. Theorists represented by J. Birkinshaw, G. Hamel, and H. Mintzberg think that these changes initiate new period of huge innovations in management, may be even the change of the paradigm. We do the research on whether practitioners see the shift in management predicted by academicians. The paper compares the ideas of academicians with results of the pilot survey of this research.
\end{abstract}

Keywords: management, management innovation, managerial functions, leadership, mental images, change.

JEL Classification: M10; M12; M19.

\section{Introduction}

The world management is usually explained in three ways. First, management is a set of activities that help us to achieve objectives. Second, management is a group of people (managers) or the profession. Third, management is a science.

In this paper, we work with all three understandings.

Management as a set of activities develops through the whole history of humankind. Management as the science develops in past 150 years. Through all these times management has to adjust to changing environment. Medieval peasant did different managerial activities and needed different managerial tools then the merchant, the craftsman or the king. Industrial era management came with totally new tools and methods, and many latest tools and methods are different from these used by our forefathers just because they help us do things and settle situations they did not know about. All these changes in the theoretical and practical field of management can be called management innovations. Management innovations together with technological innovations help to develop our globalised knowledge society step by step, century to century.

Looking at the latest theory and practice of management, some authors think that management innovations are over as there is nothing new to explore. E.g. we have all available knowledge on how to manage. On the other hand, some authors think that opposite is true and that we are facing big changes and big explorations in the same field.

Our paper discusses this topic from two perspectives. The theoretical perspective indicates that we may be facing the change of paradigm in management. The analytical part brings the result of the pilot survey of the research that is trying to find first symptoms of these changes in practical management.

\section{Management}

Literature provides us with many definitions of management. One of the first theorist who tried to explain the world management was H. Fayol. He understands management as managerial functions; to manage means to forecast and to plan, to organise, to command, to co-ordinate and to control (Fayol 1916).

Management is the organization and coordination of the activities of a business in order to achieve defined objectives. Management is often included as a factor of production along with machines, materials, and money. Practice of modern management originates from the $16^{\text {th }}$ century study of low-efficiency and failures of certain enterprises, conducted by the English statesman Sir Thomas More (1478-1535). According to the management 
guru Peter Drucker, the basic task of management includes both marketing and innovation (Businessdictionary 2016). We can also define management as interlocking functions of creating corporate policy and organizing, planning, controlling, and directing an organization's resources in order to achieve the objectives of that policy (Businessdictionary 2016). By H. Koontz and C. O'Donnell management is an art of getting things done through and with the people in formally organized groups. It is an art of creating an environment in which people can perform and individuals and can co-operate towards attainment of group goals (Koontz, O'Donnell 1968).

Management involves coordinating and overseeing the work activities of others so that their activities are completed efficiently and effectively. We already know that coordinating and overseeing the work of others is what distinguishes a managerial position from a non managerial one. However, this doesn't mean that managers can do what they want anytime, anywhere, or in any way. Instead, management involves ensuring that work activities are completed efficiently and effectively by the people responsible for doing them, or at least that's what managers aspire to do (Robins, Coulter 2012). P. Drucker also saw management as five practices: setting objectives, organising, motivating and communicating, measuring and developing people (Murray 2010).

\section{Management innovations}

Much attention has already been paid to technological, process, services, and strategic innovations. Management innovation is the new topic of the field of theory of innovation though management innovations have always been important factor of development of society. Management innovation is the invention and implementation of a new to the state of the art and is intended to further organizational goals (Birkinshaw et al. 2008). Motivation theories, divisional structure, process management may be given as an example.

Significant management innovations cause the change of management paradigms. A paradigm is a model of reality, or the theory of acceptance of reality, or the worldview. It's the frame on which basic relations are constructed. Generally said it's the way we understand the world and interpret its development. A period when research is based on some paradigm is very intense. Scientists take the paradigm as the base for their work and the explanation of reality. The paradigm has to be interesting and attract a big group of researchers and provide the space for re- search. Anomalies are ignored, the generation of scientists is fully attracted with the paradigm and anomalies are treated as exceptions, or are explained in some logical way based on the paradigm (Kuhn 1962).

Management as a science and its development is related to development of technology in industrial revolution. Three big innovations that created new paradigm in management can be identified since the beginning of the industrial revolutions. The first was the Adam Smith's division of labour, the second scientific management of F. W. Taylor and the third is the human relations movement.

Division of labour idea relates primarily to the specialization of the labour force, essentially the breaking down of large jobs into many tiny components. Under this regime each worker becomes an expert in one isolated area of production, thus increasing his efficiency. The fact that labourers do not have to switch tasks during the day further saves time and money. Although Smith recognized that forcing individuals to perform mundane and repetitious tasks would lead to an ignorant, dissatisfied work force (The Victorian Web 2016), his idea of division of labour solved the problem of lack of qualified workforce for developing factories and actually accelerated industrial revolution.

Scientific management represented by F. W. Taylor, and his followers, for example H. Ford, the Gilbreths, H. L. Gantt applied mechanistic rules on organisation Labour productivity was increased by order, discipline, formal organisational structure and choice of employee based on the needs of the work. The whole system was supported by task motivation. European authors like H. Fayol, M. Weber and T. Bata applied scientific management on the work of manager. Organisation was understood as a machine, employees its parts, managers the control unit.

Elton Mayo started human resource movement in management. His experiments showed that logical factors were far less important than emotional factors in determining productive efficiency and that it is necessary to satisfy personal, subjective social needs of employees as well as the company's productive requirements (George 1968). Works of A. Maslow, F. Herzberg, McGregor and others on motivation changed the ways of understanding management.

Though human resource movement developed in the first half of the $20^{\text {th }}$ Century, scientific management paradigm is very strong and many managers still manage their organisations in this way, especially in paternalistic and individualistic cultures (Hofstede et al. 1997). 
Hamel and Breen (2013) write that every invention, management included, develops in $\mathrm{S}$ shaped growth curve. E.g. it develops from emergence through maturity to decline. First the growth of new knowledge and ideas is slow, later fast and then it declines in a negative acceleration phase. $S$ curve of management as a science started at the end of $18^{\text {th }}$ Century by A. Smith's division of labour. The development of new ideas was slow till the last two decades of the $19^{\text {th }}$ Century when scientific management started. The $20^{\text {th }}$ Century brought huge development of management innovations but at the moment, management seems to be in or over its maturity phase and number of new management innovations is low. Management gets to similar situation like natural sciences at the end of the $19^{\text {th }}$ Century when some theorists even thought that everything was invented and that there was no potential for future development. The reality was different, of course.

S curve cannot be swindled; new development must start on the new $\mathrm{S}$ curve based on different quality. The question is what it will look like.

\section{Management and leadership - search for new paradigm?}

The declining number of important management innovations and search for something new caused that the world management and manager have been replaced by words leadership and leader in past 20 years (Mintzberg 2009). Management become understood as the set of techniques and tools, leadership as a visionary profession, e.g. management is doing things right; leadership is doing the right things (Drucker, Wilson 2001). With this approach to management, it is obvious that it is not popular to be manager and manage other people as leadership seems to be something better then management. On the other hand, leadership put emphasis on non direct influencing, soft methods, creation of environment, empowering.

The obsession by leadership indicates that the old paradigm of scientific management that is still rooted in practices of many organisations needs to be replaced by something else, something more human. But at the same moment everyone knows that it cannot be abolished totally as it still has its place in many fields and organisations. The fight between the scientific management paradigm and human resource movement paradigm reflects in two theories of organisation, organic and mechanistic (Ivanko 2013).

The followers of the mechanistic concept of organization see organization as something similar to a mechanism, having the general characteristic of a complete machine. To them organization means similarly as a machine, a depersonalized device making possible the system of work conceived of upon rational bases. Such a device must work without friction, without errors caused by human weaknesses; such a device should be, as a rule, superior to men (Ivanko 2013).

The followers of the organic (biologist) theory of organization compare the organization with a living organism. To them organization means a living natural whole that has purposefully linked parts, organs, each of them performing a special function, that in the manner that their parts and their functions are mutually linked and coordinated so that the purposeful performing of a joint task is ensured. Their opinion is that organization should be build after the pattern of a living organism, there should be build in the organization also all those regulatory mechanisms that can be found in each live human being (Ivanko 2013).

It is obvious that living organisms and machines behave differently and are differently managed. It is also obvious that supporters of each theory understand management differently. Organisations based on mechanistic concept are managed by orders, instructions and programmes; organizations based on organic principles depend more on right environment, conditions and nutrition (Zelený 2014). E.g. they are more led them managed.

Coincidental use of terms management and leadership leads to confusion about what is management and what is leadership, what their boundaries are and causes the mishmash in theory, terminology and practice. Anyway, obsession by leadership indicates increasing importance of human side of management.

There are many different concepts of leadership. In our research we understand leadership as Kouzes and Postner (2002), Richards and Engle (1986), Northouse (2010), and Roach and Behling (1984). Kouzes and Postner (2002) define leadership as a relationship between those who aspire to lead and those who choose to follow. Richards and Engle (1986) believe that leadership is about embodying values, and creating the environment within which things can be accomplished. Northouse (2010) writes that leadership is a process whereby an individual influences a group of individuals to achieve a common goal. Roach and Behling (1984) see leadership similarly as the process of influencing the activities of an organized group toward goal achievement. 


\section{Is knowledge economy changing management?}

Knowledge economy or knowledge-based economy as we globally experience now is economy where increasing relative share of the gross domestic product is attributable to "intangible" capital (Abramovitz, David 1996). It can be also defined as production and services based on knowledge-intensive activities that contribute to an accelerated pace of technological and scientific advance as well as equally rapid obsolescence. The key components of a knowledge economy include a greater reliance on intellectual capabilities than on physical inputs or natural resources, combined with efforts to integrate improvements in every stage of the production process, from the $R \& D$ lab to the factory floor to the interface with customers (Powell, Snellman 2004).

Knowledge, the major source and tool of knowledge economy is due to its tacit dimension, of an intangible character. The intangible character of knowledge leads to specifics of knowledge work. These specifics complicate the management in organisations. The specifics of knowledge work are most visible when knowledge work is compared to nonknowledge work.

Table 1 shows that the differences between knowledge and non-knowledge work are considerable. Knowledge and not the material element is the major raw material for knowledge work. As opposed to non-knowledge work, the most important part of knowledge work happens in the heads of employees even though the final result of their work has a manual character. It cannot be observed and controlled, and it is not linear. The results of knowledge work may differ from the short and long term perspective, which causes problems with standards, measurement and evaluation. Knowledge work usually requires employees with a much better education in a certain field. Due to the intangible character of knowledge it also requires a person who can work and make decisions independently. Such people are called knowledge workers.

Knowledge workers are often highly regarded by employers for their innovation and creativity, as these are both considered important elements in an organisation's ability to survive and prosper in an increasingly competitive and fast-changing environment. In private industry, innovation and creativity are needed to bring new or improved products and services to the market, while there is a greater need for public sector employees to be innovative and creative as the government seeks significant improvements and change in the delivery of public services (Brinkley et al. 2009).

Reboul et al. (2006) highlights specifics of knowledge workers as follows. The knowledge worker's main work tool is his brain. Therefore losing a knowledge worker is a loss of knowledge, too. When a knowledge worker is replaced, the one who replaced him will do the same knowledge work differently. A knowledge worker uses knowledge at his work - he creates, distributes or applies explicit as well as tacit knowledge. A knowledge worker's position requires continuous learning and improving. The productivity and quality of a knowledge worker's work is hard to measure. Knowledge workers manage their days. Their positions require creativity, innovation and problem solving skills. That is why knowledge workers don't like to be told how to do things (Reboul et al. 2006).

Table 1. Differences between knowledge and non-knowledge work (Source: Bell 1973)

\begin{tabular}{|c|c|c|}
\hline Characteristics & $\begin{array}{c}\text { Non-knowledge } \\
\text { work }\end{array}$ & Knowledge work \\
\hline $\begin{array}{l}\text { Major raw } \\
\text { material }\end{array}$ & $\begin{array}{l}\text { Material } \\
\text { elements }\end{array}$ & Knowledge \\
\hline Process of work & Obvious & Hidden \\
\hline Work visibility & High & Low \\
\hline Links to results & $\begin{array}{l}\text { Direct and } \\
\text { immediate }\end{array}$ & $\begin{array}{l}\text { Non direct, } \\
\text { effects delayed }\end{array}$ \\
\hline Knowledge & $\begin{array}{l}\text { Concentrated in } \\
\text { the hands of } \\
\text { managers }\end{array}$ & $\begin{array}{l}\text { Diffused in the } \\
\text { heads of } \\
\text { employees }\end{array}$ \\
\hline Power based on & $\begin{array}{l}\text { Position of the } \\
\text { employee in } \\
\text { formal and } \\
\text { power structures } \\
\text { of the organisa- } \\
\text { tion }\end{array}$ & $\begin{array}{l}\text { Profession, } \\
\text { knowledge and } \\
\text { position of the } \\
\text { employee in } \\
\text { power structures } \\
\text { of the organisa- } \\
\text { tion }\end{array}$ \\
\hline Work is & Linear & Non linear \\
\hline $\begin{array}{l}\text { Way the employ- } \\
\text { ee responds to } \\
\text { various situations }\end{array}$ & $\begin{array}{l}\text { Based on posi- } \\
\text { tion and task }\end{array}$ & $\begin{array}{l}\text { Employee evalu- } \\
\text { ates the situation } \\
\text { and decides the } \\
\text { way to respond } \\
\text { to it himself }\end{array}$ \\
\hline $\begin{array}{l}\text { Standards are } \\
\text { developed }\end{array}$ & By others & $\begin{array}{l}\text { Employee } \\
\text { himself }\end{array}$ \\
\hline $\begin{array}{l}\text { Control is di- } \\
\text { rected to }\end{array}$ & Employee & $\begin{array}{l}\text { Work and results } \\
\text { of work }\end{array}$ \\
\hline $\begin{array}{l}\text { Performance is } \\
\text { measured by }\end{array}$ & $\begin{array}{l}\text { Accordance } \\
\text { with standards }\end{array}$ & $\begin{array}{l}\text { Employee } \\
\text { contribution }\end{array}$ \\
\hline Role of employee & Tool & Agent \\
\hline
\end{tabular}


The growing importance of knowledge work and growing numbers of employees who can be classified as knowledge workers changes power relations in organisations. Managers used to be the people who had more knowledge, more decision making rights and the right to control their subordinates. When knowledge work is involved, power shifts from managers to subordinates. They have more knowledge and they often understand what they are doing much more than their managers. Many of them make the final control of their product or service themselves (Mládková 2012).

Managing people in knowledge economy in scientific management style may be contra productive. Suff and Reilly (2005) write that knowledge workers are more responsive to being "pulled" rather than being "pushed". E.g. specifics of knowledge work and increasing numbers of people who work in knowledge intensive jobs is probably the reason why leadership is so popular.

\section{Research objectives and methodology}

The major objective of the research we started at the end of year 2015 is to find out whether knowledge economy initiates some innovations (or even the change of paradigm) in management and what these innovation look like.

The research started with the review of literature. The methodology used for the review of literature was as usual for this type of theoretical research, e.g. we used methods that allow interlinking separated pieces of knowledge like analysis and synthesis, comparison, induction, deduction, abstraction, generalisation and critical thinking. The literature on management innovations turn out to be limited. It is new topic that is going to be explored more in future. To be able to build the theoretical background for our research, we had to approach it indirectly and we collected, described and we also evaluated different approaches and different ideas on management, development of management and history of management. The data used are secondary data collected from traditional and electronic media.

The empirical part started with the pilot survey in which we asked our respondents to list 10 meanings word management has for them. The objective of this part of the survey is to find out what is current understanding of management, what management means for people. We want to find out what paradigm of management people support. Is it the scientific management or human resource management or something different? The chosen style of survey allows us to capture ideas of respondent without biasing them by our own ideas.

The results of the pilot were evaluated by the grounded theory (Glaser, Strauss 1967). Grounded theory is a systematic methodology that enables to search for and conceptualize social patterns and structures. It is based on collection of qualitative data in which repeated ideas, concepts and structures are searched for. The more data is collected, the more structures and patterns are obvious. Grounded theory may lead to identification of new concepts and theories.

\section{Respondents}

The pilot survey included 46 respondets. The characteristics of respondents are in Table 2. Percentages were rounded off.

Table 2. Respondents of pilot survey (Source: compiled by author)

\begin{tabular}{l|c|c}
\hline \multicolumn{1}{c|}{ Characteristics } & Nb. & $\%$ \\
\hline Woman & 30 & 65 \\
\hline Men & 16 & 35 \\
\hline Age $20-30$ & 46 & 100 \\
\hline Students total & 46 & 100 \\
\hline Only students & 19 & 41 \\
\hline Working & 27 & 59 \\
\hline
\end{tabular}

All 46 respondents of the pilot survey were MA students of Faculty of Business Administration, University of Economics Prague. We decided for this pool of respondents for few reasons. First, they are available group of respondents; we interviewed them after the exam from Advanced Management Studies. Second, they have both theoretical and practical experience in management. Majority of them works or have working experience. Third, they are young generation, in literature labelled as generation X or Z (Schroer 2015). Literature mentions that this generation is characteristics by freedom, flexibility, cooperativeness, curiosity, integrity, entertainment, swiftness and innovativeness (Tapscott 2008). So who else then this generation should feel management innovations or the change in management paradigm?

Out of all respondents, $65 \%$ were female and $35 \%$ male. They all belonged to age interval $20-30$ year; 42 of them $(91 \%)$ were in the interval $20-25$ years. At the moment of the interview, $41 \%$ respondents did not have different job then being students, $51 \%$ had job, and 6 respondents $(13 \%)$ worked as managers. 


\section{Results of the survey}

Application of grounded theory started with definition of substantive area. It is management. Then we followed with open coding of data obtained from respondents. As already mentioned we asked our respondents to list 10 meanings word management has for them. In open coding the meaning was included as many times as it appeared in responses of respondents except of situation when the respondent used synonyms for one meaning, for example he used the word "leadership" and its Czech equivalent "vůdcovství". In the research we collected 422 meanings (some respondents gave less than 10 meanings). Open coding showed following core categories:

Table 3. Core categories after open coding

(Source: compiled by author)

\begin{tabular}{l|c}
\hline \multicolumn{1}{c|}{ Category } & $\mathrm{Nb}$. \\
\hline Leadership & 61 \\
\hline Managerial activities & 54 \\
\hline Organising & 49 \\
\hline Planning & 36 \\
\hline Science & 35 \\
\hline Profession & 31 \\
\hline Decision making, responsibility & 23 \\
\hline Motivation & 22 \\
\hline Requirements on managerial profession & 19 \\
\hline Controlling & 16 \\
\hline Statute, power, money & 15 \\
\hline Knowledge, professionalism & 15 \\
\hline Innovation & 12 \\
\hline Firm & 12 \\
\hline Other & 10 \\
\hline Communication & 8 \\
\hline Typical for mng. profession (stress, etc.) & 6 \\
\hline HR & 5 \\
\hline Art & 4 \\
\hline Employees & 3 \\
\hline Systems & 3 \\
\hline Corporate image, culture & 3 \\
\hline
\end{tabular}

After open coding (Table 3), the strongest category was leadership, it was mentioned $61 \mathrm{x}$ as a meaning of the word management in responses of our respondents. The second strongest category was managerial activities (54x). It was followed by two managerial functions - organising (49x) and planning (36x) (including strategy, vision and mission creation). Respondents mentioned $35 \mathrm{x}$ that management is a science and $31 \mathrm{x}$ that management is a profession; motivation was mentioned $22 \mathrm{x}$. Requirements on managerial profession (19x) include such factors like time management, coopera- tion, delegating, effectiveness, reliability, and relationship management. Managerial function controlling was mentioned only $22 x$, HR activities $5 x$.

Open coding brought few surprises; leadership scored more time then managerial activities (in general, not classified to individual activities). As for managerial functions, organising and planning got the highest scores. Decision making and motivation appeared only $23 \mathrm{x}$ and $22 \mathrm{x}$ which is very low. Controlling was mentioned only $16 x$. Communication even only $8 \mathrm{x}$.

Selective coding started with elimination of categories that explain the word management in way not consistent with the objective of our research (substantive area). Categories science, profession, requirements on management, statute, knowledge, other, typical for managerial profession, art, employees, corporate image, systems were excluded. Categories organising, planning, decision making, motivation, controlling, innovation, communication, and HR are important activities (some even managerial functions) and as such they were added to the category managerial activities. Selective coding gave two big categories, leadership and managerial activities:

Table 4. Core categories after selective coding (Source: compiled by author)

\begin{tabular}{l|c}
\hline \multicolumn{1}{c|}{ Category } & $\mathrm{Nb}$. \\
\hline Leadership & 61 \\
\hline Managerial activities & 225 \\
\hline
\end{tabular}

The selective coding shows (Table 4) that our respondents understand management first of all as managerial activities. Leadership is the second category but not as strong as managerial activities and it supposed it to be after the literature review. The pilot survey showed that our respondents understand management as managerial activities, e.g. in very traditional way in accordance with the paradigm of scientific management.

\section{Conclusions}

Literature on management and management innovations indicates that management as understood in $20^{\text {th }}$ Century may meet it limits in globalised knowledge economy. Knowledge economy is built on work with knowledge that is an intangible asset. Intangibility of knowledge leads to specifics of knowledge work; it happens in heads of employees, cannot be controlled, is non-linear, etc. Movement based on command and control stop to bring good results. Requirements of knowledge 
economy probably cause huge popularity of leadership that offers more "soft" methods and tools.

These days we are in the period when management will have to change. Management seems to be in or over its maturity phase and number of new management innovations is low. Both the theory and practice seem to turn around in the circle adjusting and reusing methods and tools that have been invented in past 150 years. We are probably close to final part of S curve of development of management and the question whether there will be or no new $\mathrm{S}$ curve based on some new paradigm of management is still without answer. In our opinion it is the time to start the research to find out what is happening (or if something is happening at all).

The major objective of the research we started at the end of year 2015 is to find out whether knowledge economy initiates some innovations or the change of paradigm in management and what these innovation look like. We started the empirical part of the research with the pilot survey on how people understand the word management. 46 student of our faculty were respondents of this survey and we collected 422 meanings.

The analysis of these meanings by the Grounded theory showed that our respondents understand management as managerial activities, e.g. in very traditional way in accordance with the paradigm of scientific management. They put emphasis on managerial functions of organising and planning. Leadership that was represented by softer tools (methods and approaches like support, being the model, development of employees, creation of climate, informal authority, intelligence and inspiration) in the results of the survey got much less important scores. The survey did not identify any important management innovation or signal of potential paradigm shift.

Up to the orientation of our respondents to the paradigm of scientific management, the survey brought other surprises. One of them was low score of communication, HR and systemic approach to management (interviews were held after the exam from the course that put emphasis on systemic approach to management).

Even though the type of respondents and methodology we used have their limits, the survey tested the methodology and it turn out to be acceptable. Future surveys are planned. We would like to extend the research and interview respondents of different jobs, age and from different types of organisations, both subordinates and managers. We also plan extending the research on people in knowledge intensive industries. We decided to go on a qualitative research.

\section{References}

Abramovitz, M.; David, P. A. 1996. Technological change and the rise of intangible investments. The U.S. economy's growth-path in the twentieth century, in Employment and growth in the knowledgebased economy. Paris: OECD, 35-60.

Bell, D. J. 1973. The coming of post-industrialist society: a venture in social forecasting. New York: Basic Books.

Birkinshaw, J.; Hamel, G.; Mol, M. J. 2008. Management innovation, Academy of Management Review 33(4): 825-845.

http://dx.doi.org/10.5465/AMR.2008.34421969

Brinkley, I., et al. 2009. Knowledge workers and knowledge work. A knowledge economy programme report [online], [cited 11 June 2015]. Available from Internet:

http:/www.theworkfoundation.com/Assets/Docs/ Knowledge\%20Workers-March\%202009.pdf

BusinessDictionary. 2016a. Management [online], [cited 17 January 2016]. Available from Internet: http://www.businessdictionary.com/definition/man agement.html

Drucker, P. F.; Wilson, G. 2001. The essential drucker, Vol. 81. Oxford: Butterworth-Heinemann.

Fayol, H. 1916. General principles of management. Paris: Dunod.

Hamel, G.; Breen, B. 2013. The future of management. Harvard Business Press.

Hofstede, G., et al. 1997. Cultures and organizations. New York, NY: McGraw Hill.

George, C. S. 1968. The history of management thought. Englewood Cliffs, NJ: Prentice-Hall.

Glaser, B. G., Strauss, A. L. 1967. The discovery of grounded theory. Chicago: Aldine.

Ivanko, S. 2013. Modern Theory of Organization [online], [cited 26 August 2014]. Available from Internet: http://www.fu.uni-lj.si/fileadmin/usrfiles/Mednarodna_pisarna/Modern_Theory_of_Or ganization_2013_04.03.2013.pdf

Koontz, H.; O’Donnell, C. 1968. Principles of management. An analysis of managerial functions. McGraw-Hill.

Kouzes, J.; Posner, B. 2002. The leadership challenge. $3^{\text {rd }}$ ed. San Francisco: Jossey Bass. ISBN 0-78795678-3.

Kuhn, T. S. 1962. The structure of scientific revolutions. University of Chicago press.

Mintzberg, H. 2009. Managing. Berrett-Koehler Publishers.

Mládková, L. 2012. Management of knowledge workers. Bratislava: Iura Edition.

Murray, A. 2010. The Wall Street journal essential guide to management: lasting lessons from the best leadership minds of our time. Harper Collins. 
Northouse, P. G. 2010. Leadership: theory and practice. $5^{\text {th }}$ ed. Sage Publications. ISBN 978-1-4129-7488-2.

Powell, W. W.; Snellman, K. 2004. The knowledge economy, Annual Review of Sociology 30: 199-220. http://dx.doi.org/10.1146/annurev.soc.29.010202.1 00037

Suff, P.; Reilly, P. 2005. In the know: reward and performance management of knowledge workers [online], [cited 12 July 2011]. Institute of Employment Studies. 2005. Available from Internet: http://www.employmentstudies.co.uk/pdflibrary/mp47.pdf

Reboul, C., et al. 2006 Managing knowledge workers: the KWP matrix, in Conference Proceedings MOMAN 06, 2 February 2006, Prague. ISBN 8086596-74-5.

Richards, D.; Engle, S. 1986, After the vision: suggestions to corporate visionaries and vision chapmions, in Gray, J. H.; Densten, I. L.; Sarros, J. C. (2003). Profilling Australian small business leadership: Working Paper Series. ISBN 1327-5216.
Roach, C. F.; Behling, O. 1984. Leaders and managers: international perspectives on managerial behavior and leadership. James, G.; Hunt, J. G., et al. (Eds.). NY: Pergamon Press. ISBN 103-377-107.

Robins, S. P.; Coulter, M. 2012. Management. $11^{\text {th }}$ ed. New Jersey: Prentice Hall.

Schroer, W. J. 2015. Generations X,Y,Z and the OthersCont'd [online], [cited 3 July 2015]. Available from Internet:

http://www.socialmarketing.org/newsletter/feature s/generation 3.htm

Tapscott, D. 2008. Grown up digital: how the net generation is changing your world. McGraw-Hill.

The Victorian Web. 2016. [Online], [cited 19 January 2016]. Available from Internet: http://www.victorianweb.org/economics/division.h tml

Zelený, M. 2014. Living organisation and organisation of life [online], [cited 9 August 2014]. Available from Internet: http://www.darius.cz/bata/bata2.html 